\title{
New Zealand's climate refugee debate grows louder
}

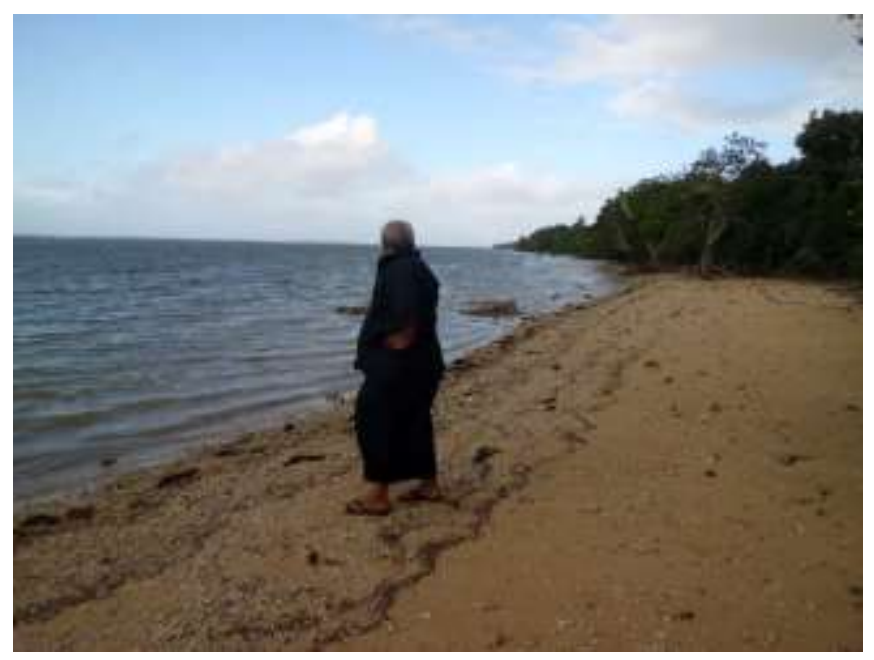

Photograph Credit: Teena Brown Pulu

Just when you thought the government couldn't worsen its unpleasantness to Pacific Islanders on the climate front, Race Relations Commissioner Dame Susan Devoy drew attention to New Zealand refusing to recognise climate refugees are real. The Human Rights Commission contended New Zealand was morally responsible to up the number of Kiribati nationals permitted residency. Seventy-five permanent residents a year wasn't enough for what was arguably a climate vulnerable state of the Pacific Islands region.

Devoy's argument was to "start planning to help our Pacific neighbours [as this seemed] the really important and 
right thing to do." Her ideas were linked to the deportation of Kiribati national, Ioane Teitiota, along with his wife and three children. In September of 2015, Teitiota lost an appeal to Associate Immigration Minister, Craig Foss, to stay in New Zealand on the grounds he was a climate refugee. Prime Minister John Key held strong views on Teitiota's case: "In my eyes, he's not a refugee, he's an overstayer."

The tricky part about Devoy's call "to help our Pacific neighbours" was determining "help" on what basis. Humanitarian grounds in relation to climate change was problematic. Geopolitically it opened up a can of worms. Legally, would New Zealand be culpable for affecting climate change in the Pacific Islands if the government acknowledged the existence of climate refugees?

The logic resembled this. Admitting there were Pacific Islanders displaced by rising sea levels and natural disasters, and opening up borders to take in people forced to move, put New Zealand in an awkward position. Would the government be legally accountable for carbon emissions? Did New Zealand's emissions exacerbate the catastrophe?

John Key's regime fell back on the division among Pacific Islanders in Kiribati, versus Pacific climate activists in New Zealand, to validate their decision not to distinguish climate refugees in policy and law. The United Nations 1951 Refugee Convention and 1967 Protocol did not accept climate refugees within its international treaty. Why would New Zealand beg to differ?

Pelenise Alofa, Kiribati Climate Action Network's national coordinator, was certain her people did not want to be classified as climate refugees. In an interview with Radio Australia, Alofa bellowed the refugee labelling disturbed her.

The word refugee, we cross it off our vocabulary; nobody wants to be a refugee. Even the word refugee is like a stick [of] mud to us. We feel sorry for the people who are refugees because the word refugee 
makes us feel less like citizens. We see how the people are treated when they come to another country, and we say no, we're not going to end up like that.

Kiribati and other low-lying atolls distressed by rising seas were by no means isolated. The Smaller Island States were regional actors. Alofa's reading of refugees as pitiable highlighted this. She alluded to boat people turned away from Australia's shores, detainees in Nauru and Manus Island detention facilities, and Middle Eastern and North African peoples descending on Europe. "We're not going to end up like that," Alofa thundered. Her scrutiny made sense: who would want to be a refugee?

The difficulty was Pacific climate lobbyists in New Zealand used climate refugee as a political term to hang their cause. 350 Aotearoa, a New Zealand branch of the climate movement 350 Organization, staged a protest outside the Queen Street branch of the ANZ Bank on Friday September 25th. The demonstration was called a "Pacific Climate Refugee Camp," exhibiting refugees on stretchers, medical supplies, and ration boxes. They wanted the bank to stop investing in fossil fuels.

A question being avoided was the social fracture between Pacific Islands and Pacific diaspora climate movements. The Smaller Island States to the Pacific Islands Forum - Cook Islands, Kiribati, Marshall Islands, Nauru, Niue, Palau, and Tuvalu - were not arguing a climate vulnerability case on the legal provision of amending refugee status under international law.

Seven heads of government made a declaration on climate change asking for recognition of "the special circumstances" that "Small Island Developing States and Least Developed Countries" endured through. Their countries desired "direct additional efforts to assist them meet the challenges of climate change."

They wanted to stay. They needed climate funds to have a fighting chance. Pelenise Alofa made that clear: "We do not 
want to leave our homes. If we leave, we leave because we cannot stay in our homes anymore, but, we want to go with dignity."

New Zealand's climate change debate had turned inward. None of the political actors - government, parliamentarians, senior bureaucrats, political activists, non-government organisations, and media - took into account the anti-climate refugee stand of Kiribati nationals living in their country.

Prime Minister John Key commended New Zealanders as "compassionate people". He envisaged public policy would accept climate refugees were real in future "decades."

What I've always said about climate change when it comes to our low-lying Pacific neighbours is that, as New Zealanders [we're] very compassionate people and if in decades a real issue presents itself, New Zealand would take that compassionate view.

Uncertainty challenged the debate. How would New Zealand coordinate an immigration agreement on climate refugees with Kiribati, when their citizens rejected the political labelling, and its application to themselves? Constructing Ioane Teitiota as the standard Kiribati climate refugee made no sense for New Zealand's relations with Pacific Islands' states if they refused to wear the label invented for them, by outsiders. 